「わが社の新製品」特集

\title{
ニューアクリル「スペリア ${ }^{\circledR} 」$ 東邦レーヨン株式会社
}

\section{上田善治}

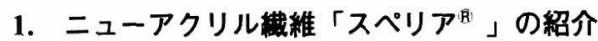

ポリエステル新合䋐に代表される，最近の合成䄉維の 多様化は, 䇝維の形状面, 機能面において, 多岐に渡っ て展開されています。この様な状況の中で，東邦レーヨ ン株式会社は，特に，アクリル䋐維に注力して来ました が, 今回, アクリル織維の弱点とされていた耐熱性を改 良し，更に，風合，抗ピリング性能に優れた，新タイプ のアクリル䄉維「スペリア®」を開発上市致しました。

「スペリアロ」は耐熱性の優れた，機能性の高いアク リル䄉維で，今までのアクリル䄉維の弱点とされてい た，アイロン掛けや，プリーツ加工を可能にしました。

更に，一般のアクリル䋐維より耐熱黄変性に優れてい る為，此の分野で高い性能を要求される，ホットカーペ ット等，家庭電気用緎維製品でも高い評価を受けていま す。

この様に「スペリアやは，優れた耐熱性や，風合 いの良さに加え，その発色性，堅牢度等と相まって，織 物や資材，各種ニット，寝装インテリア等，様々な分野 での用途が期待出来る大型新素材であり，正に，アクリ ル版新合織と言えるニューアクリル緎維です。

\section{2.「スペリア ${ }^{\circledR} 」 の$ 性質}

\section{(1)箋維の耐熱性能}

アクリル綫維はその染料発色性の良さ，ボリューム感 等の優れた性質により，ポリエステル，ナイロンと共 に，三大合成䄉維の一つとして，各々の特長を生かした 用途分野で大量消費されて来ました。しかし，近年の商 品の多様化に伴い，各䋐維の用途分野の競合が始まり， 今迄，不得意とされていた用途分野への進展も始まって います。アクリル織維の場合には，その弱点とされてい
る，耐熱性の向上が最も強く要望される所です。 ニューアクリル䄉維「スペリアア」は, 最大の特長と して，耐熱性能を挙げています。

\section{競熱伸長变化}

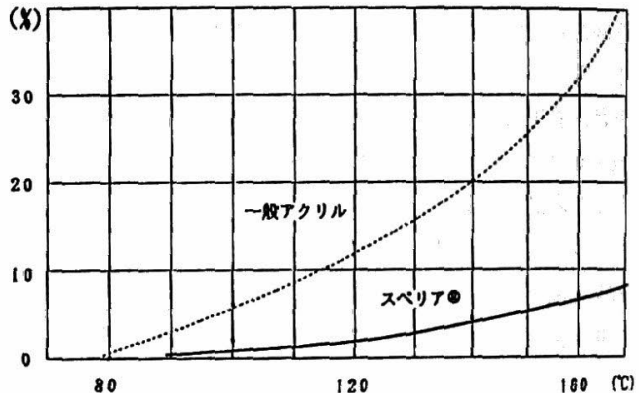

诵料: プライト3 デニールステーブル

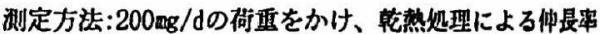

図 1 「スペリアの」の乾熱伸長変化

湿熱収稀变化

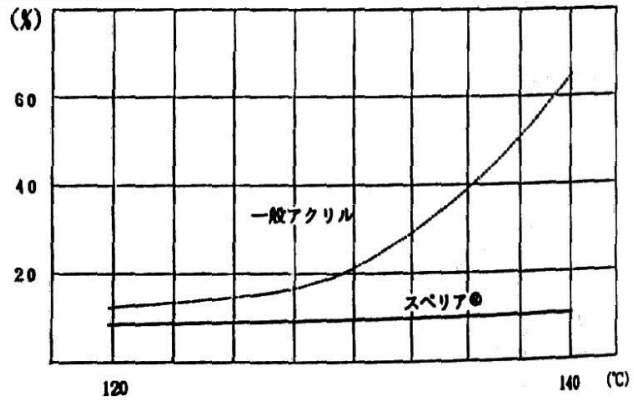

試料: プライト1.5 デニールステープル

即定方法：スチーム処理に上る収䗆率

図2「スペリア®」の温熱収縮変化

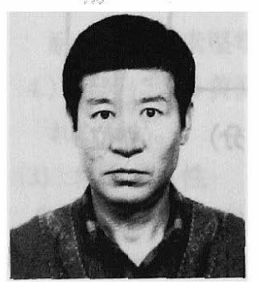

Introduction of New Acrylic Fibre "Superia" 筆者紹介 YOSHIHARU UEDA

Toho Rayon Co., Ltd., Technical Department 東邦レーヨン株式会社 加工技術部技術課 課長代理

筆者は染色加工技術が御專門で，趣味はスポーツ。

本稿では，感性豊かなアクリル䢂維に機能性を加えて誕生した新合䄉の紹介をしていたたいた。 


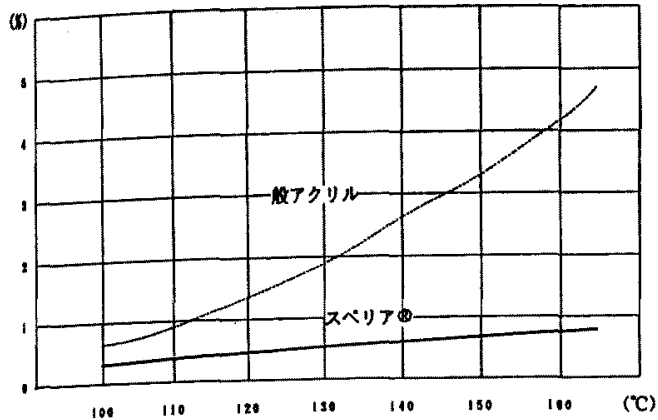

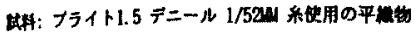

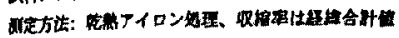

图3乾熱アイロンによる，織物の収縮变化

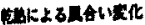

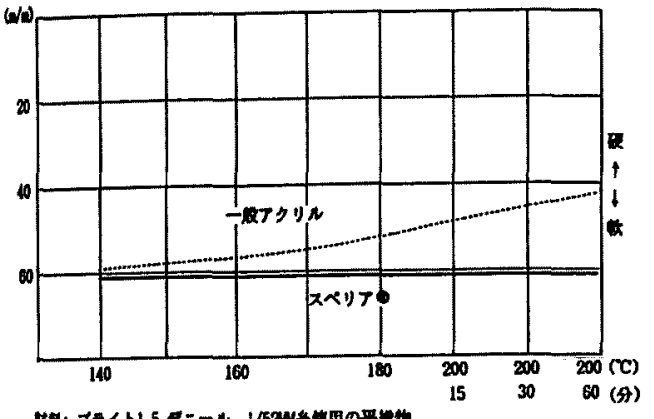

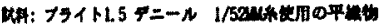

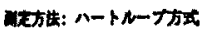

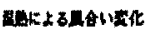

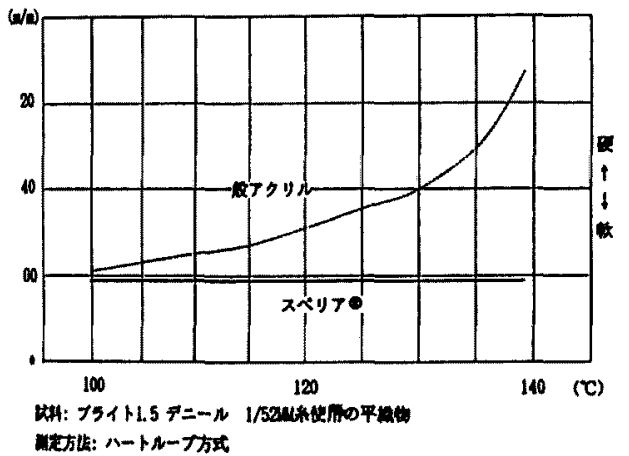

圆 4 物の乾熱・温熱による風合変化

ここでは，その耐熱性能を評洒する為，一般アクリル

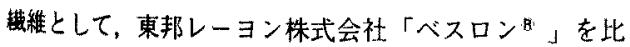
较用として用い，㢦熱性能の評価を行いました。その結 果，图1及び，図２に示される様に，「スペリア月」 は、一般のアクリル䄉維に比べ，熱による伸長，取縮率 の変化が少なく，寸法安定性に優れている事が分かりま t。

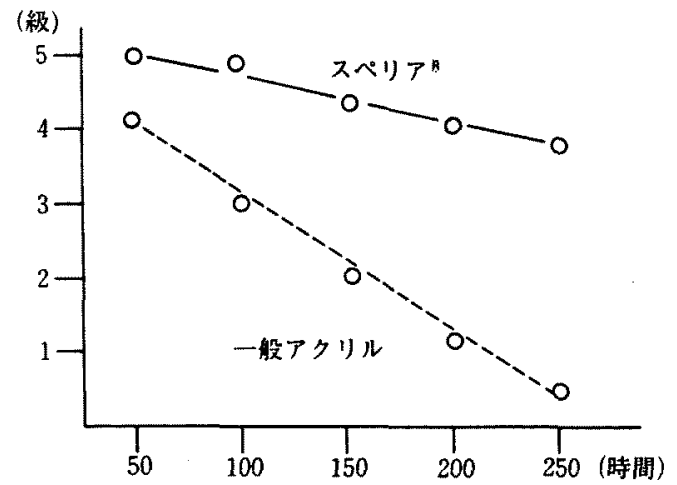

試料：フライト 2 デニール1/52系使用の天竺編地 测定方法：恒温乾燥器で乾熟 $\left(100^{\circ} \mathrm{C}\right)$

$$
\text { 黄変度はクレースケールで測定 }
$$

図 5 乾熱による黄変度

\section{(2)乾熱アイロンによる織物の収縮変化}

通常，アクリル織物の耐アイロン温度は， $120^{\circ} \mathrm{C}$ で 3 ～ 5 秒程度とされています。従って，アクリル織物の製 品や製品加工工程での取扱い条件が制限されます。

一方，「スペリア ${ }^{\mathrm{B}}$ 」は $150^{\circ} \mathrm{C} \sim 160^{\circ} \mathrm{C}$ の乾熱アイロン 掛けでも収樎は殆ど有りません。又, 風合変化の面でも アイロンによる影㽫は殆ど受けません。

この様に、「スペリアロ」は従来，アクリル瀻維の進 出が制限されていた，織物用途への应販が可能に成ると 共に, $110^{\circ} \mathrm{C} \sim 120^{\circ} \mathrm{C}$ の高压スチームで処理する事によ ク，プリーツセット加工も可能になり，アクリル緎維の 優れた染料発色性や堅牢度と共に，遅れていた，織物分 野への進展を可能にした，画期的なアクリル䋐維と言え ます。

\section{(3)酎熱黄変性能}

アクリル䋐維の熱処理による䋐維の着色は，通常の加 工条件や取扱いでは問題となる事はありません。

しかし，最近の用途多様化による，家庭電気紻維製品 用途への参入等，特に族しい耐熱黄变性能を要求される 分野への進展は，末だ，制限されています。

「スペリア」は耐熱黄変性能についても，佰れた性 能を持っています。例えば，ホットカーペット等に適用 されている，乾熱黄変性能 $100^{\circ} \mathrm{C} \times 240$ 時間で 3 - 4 級と 言う厳しい基準にも対応出来るニッーアクリル䄉維で す。

(4)抗ピリング性能

合成織維の特長の一つである，短縺維強力の強さは， 反面，織物や二ット製品にした場合ピリング（毛玉）に 成り易く，製品取り扱い上問題になる事があります。 


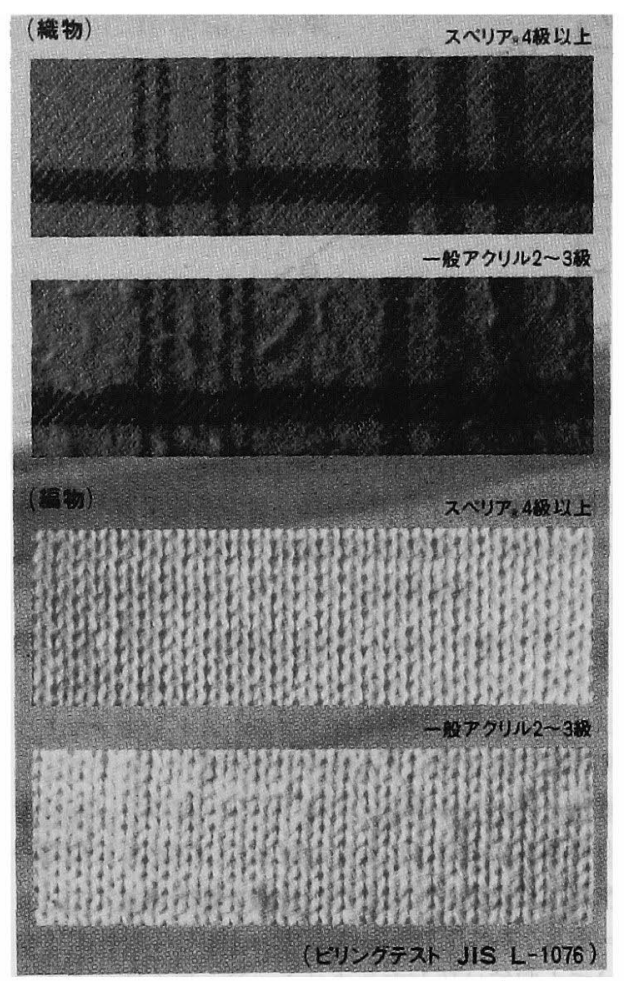

図 6 抗ピリング性能

試料：ブライト 2 デニール $2 / 52$ 采使い

綾織

通常のアクリル䄉維もこの性質を持ち, 製品により, 制限される場合があります。

「スペリアき」は優れた耐熱性能と共に, 織維の構造 的な特徵から，優れた抗ピリング性能を持っています。
図 6 に示される様に, 通常のアクリル織物に比べ, 実用 的な抗ピリング性能が得られます。

(5)豊かな風合と鮮明な色合

アクリル綫維はソフトな風合が特長の䄉維です。「ス ペリアロ」」は，優れた機能性に加え風合面でも，より一 層の柔らかな風合を持ち更に, 特有のぬめり感とシルキ 一な触感を兼ねそなえています。この為, 戥細な感性を 求められるファッション素材から機能性を追求される資 材まで様々用途で使用出来る, 感性と機能性を兼ねそな えた,ニューアクリル䄉維です。

\section{3. ニューアクリル「スペリア ${ }^{\mathbb{E}}$ の用途}

ニューアクリル「スペリア゙」は, 東邦レーヨン株式 会社における, 次世代の基幹アクリル織維として, 当 面, $150 \mathrm{~T} /$ 月の生産体制を旉き, 多彩に用途開発及び 拡販を行っています。現在の主な用途は，衣料（織物、 ジャージーセーター,レグニット等)。㖊装 (毛布類, シーツ類)。インテリア（カーテン，椅子張カーペット 類, 雑貨類)。資材 (帆布, 厚織合成皮革基布, 車雨 一ト類, フィルター芯地)。等ですが, 順次, 建設資 材, 電気部品, ジオテキスタイル等に, 用途開発の進展 が期待出来ます。

\section{4. まとめ}

鉄よりも強く，蜘の系よりも細い」と言われだイ㐰 ンの登場より約60年, 合成繊維は強さに始まり, 種々の 改良がなされて来ました。そして近年, 新合樴の登場に より, 合䋞は, 機能性と感性との調和と言う新しい段陼 に入りました。「スペリア®」もこの調和を目指した栰 維であります。感性と機能性を備えた，これらの程維は 我々の心をも豊かにしてくれると考えます。 